\title{
Persistence of Parathion Residue on Fresh West Indian Cherries and in Canned West Indian Cherry Juices
}

\author{
G. García Monge, M. E. Pérez, and R. A. Canals
}

\section{INTRODUCTION}

Parathion insecticide has been found effective in the control of the West Indian cherry fruit weevil (Anthonomus flavipes) (1)2. Considerable information has appeared in the literature on the residues of parathion $(2,3)$ on fruits, vegetables, and forage crops during recent years. Much of this work has been done in areas having quite different climatic conditions than those in Puerto Rico and often on crops of no great importance to our Island.

The work described herein was conducted to elaborate on that with parathion residues on acerolas (Malpighia punicifolia, L.) previously done in Puerto Rico (4) and, in view of impending Federal regulations, to accumulate data to support a petition for tolerance to the Food and Drug Administration.

\section{MATERIALS AND METHODS}

Three field experiments were conducted at the Isabela Substation during March and April of 1960. In the first, the field was divided into 18 plots each including 4 trees arranged in a randomized block design with 6 spray treatments including the check, replicated 3 times.

The sprays were as follows: 1,1 spray at blossom time; 2,1 spray at blossom time, a second 8 days later; 3,1 spray at blossom time, a second 8 days later and a third 8 days after the second; 4 , the last 2 sprays as in $3 ; 5$, the last spray only as in $3 ; 6$, check untreated.

Parathion was applied as a wettable powder at the rate of 1.5 pounds of the 15-percent formulation per 100 gallons of water; each tree received approximately 1 gallon of the finished spray per application. The first spray was given on March 9, 1960, the second and third on March 17 and 25 , respectively. Immediately after the last spray 1-pound samples of fruits were collected from each replicate of treatments 3, 4, 5, and 6. A 3-pound sample was also obtained from a nearby acerola field that received no

1 Assistant Chemist, Entomologist, and Research Assistant in Chemistry, respectively, Agricultural Experiment Station, University of Puerto Rico, Rio Piedras, P.R. The authors wish to express their sincere gratitute to Technical Director $\mathbf{R}$. Sánchez Nieva of the Food Technology Laboratory of the Agricultural Experiment Station of the University of Puerto Rico, for canning the West Indian cherry juices.

2 Italic numbers in parentheses refer to Literature Cited, p. 14. 
insecticide. This was done to determine possible contamination of experimental checks while applying the insecticide. Subsequent samples from the same plot were obtained 1, 2, and 4 days after the last spray.

In the second field experiment a grove was divided into 20 plots of 5 trees, each arranged in a randomized-block design with 5 spray treatments including the check, replicated 4 times.

The sprays were as follows: 1,1 at blossom time, a second 14 days after; 2,2 sprays 7 and 14 days after blossom time; 3,1 spray at blossom time, a second 7 days after, and a third 7 days after the second; 4 , the last 2 sprays as in $3 ; 5$, the last spray only as in $3 ; 6$, check untreated.

The first spray was given on March 30,1960; the second and third, on April 6 and 13, respectively. Parathion was applied at the same rate as in the previous experiment. Immediately after the last spray, 1-pound fruit samples per replicate of treatments $1,2,3$, and 5 were collected.

In the third field experiment half of the grove was sprayed with parathion at the same rate as the other two, but using three sprays, the maximum number which might control the fruit weevil. The windward half of the grove was not sprayed. One-hundred-pound fruit samples were obtained from each half of the grove 6 days after the last spray. The fruits were canned at the Food Technology Laboratory of this Station. The juices were extracted with a press at a pressure of 7,000 pounds and pasteurized at a temperature of $190^{\circ} \mathrm{F}$.

The Averell and Norris method was used for the determination of parathion on the fresh acerola and juice. The senior author has adapted and evaluated this method for fresh acerolas (5) as well as for its juice. Bioassay analyses were made only for the first experiment, using the ebony strain of Drosophilia melanogaster as the test organism, following a modification of the Wylie's procedure (6). A sugarcane-molasses medium was used instead of squash.

\section{RESULTS AND DISCUSSION}

The tolerance established by the Food and Drug Administration for cherries and citrus fruits is 1 p.p.m. parathion. The results shown in tables 1 and 2 and figures 1 and 2 indicate that after the first day the parathion residues were below 1 p.p.m. On the fourth day, the parathion residues practically disappeared. Bioassay analysis also showed similar values for the first and fourth days, as may be seen in table 1.

The parathion residues determined in 15 cans of the processed juice from the treated section of the grove were well below the tolerance. They varied from zero to 0.15 p.p.m. as compared to the untreated which varied from zero to 0.07 p.p.m.

The general concensus of opinion is that parathion residues ( $(3)$ break 
TABLE 1.-Parathion contents of West Indian cherry at time of sampling experiment 1 at the Isabela Substation

\begin{tabular}{|c|c|c|c|}
\hline \multirow{2}{*}{ Spray treatment No. and description } & \multicolumn{2}{|c|}{ Parathion residues (range) } & \multirow{2}{*}{$\begin{array}{l}\text { Period of fruit } \\
\text { sampling after } \\
\text { last spray }\end{array}$} \\
\hline & Chemical & Bioassay & \\
\hline $\begin{array}{l}3 ; 3 \text { sprays used at blossom and } 8 \\
\text { and } 16 \text { days after }\end{array}$ & $\begin{array}{c}\text { P.p.m. } \\
0.53-0.94 \\
.27-.51 \\
.04-.08 \\
0 \quad-.11\end{array}$ & $\begin{array}{c}\text { P.p.m. } \\
0.50-1.60 \\
.16-.300 \\
0 \quad-.002 \\
0 \quad-0\end{array}$ & $\begin{array}{c}\text { Days } \\
0 \\
1 \\
3 \\
4\end{array}$ \\
\hline $\begin{array}{l}4 ; 2 \text { sprays } 8 \text { and } 16 \text { days after blos- } \\
\text { som }\end{array}$ & $\begin{array}{l}.50-.81 \\
.09-.60 \\
0 \quad-0 \\
0 \quad-.02\end{array}$ & $\begin{array}{c}.82-1.20 \\
.07-.86 \\
.053-.45 \\
0 \quad-0\end{array}$ & $\begin{array}{l}0 \\
1 \\
3 \\
4\end{array}$ \\
\hline 5; 1 spray, 16 days after blossom & $\begin{array}{r}.73-1.14 \\
.09-.30 \\
0 \quad-.20 \\
.03-.06\end{array}$ & $\begin{array}{c}.60-1.20 \\
.11-.33 \\
.012-.021 \\
0 \quad-0\end{array}$ & $\begin{array}{l}0 \\
1 \\
3 \\
4\end{array}$ \\
\hline 6 ; check & 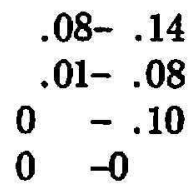 & $\begin{array}{ll}0 & -.004 \\
0 & -.02 \\
0 & -.002 \\
0 & -0\end{array}$ & $\begin{array}{l}0 \\
1 \\
3 \\
4\end{array}$ \\
\hline
\end{tabular}

TABLE 2.-Parathion contents of West Indian Cherry at time of sampling experiment 2 at the Isabela Substation

\begin{tabular}{|c|c|c|}
\hline Spray-treatment description & $\begin{array}{l}\text { Parathion residues } \\
\text { (range) }\end{array}$ & $\begin{array}{l}\text { Period of fruit } \\
\text { sampling after } \\
\text { last spray }\end{array}$ \\
\hline & P.p.m. & Days \\
\hline 2 sprays, at blossom and 14 days after & $\begin{array}{r}0.38-1.94 \\
.05-.16 \\
.06-.11 \\
0 \quad-.05\end{array}$ & $\begin{array}{l}0 \\
1 \\
3 \\
5\end{array}$ \\
\hline 2 sprays, 7 and 14 days after blossom & $\begin{array}{l}.54-1.94 \\
.14-.54 \\
.05-.15 \\
0\end{array}$ & $\begin{array}{l}0 \\
1 \\
3 \\
5\end{array}$ \\
\hline 3 sprays at blossom and 7 and 14 days after & $\begin{array}{r}.26-1.46 \\
.08-.25 \\
.02-.09 \\
0 \quad-.02\end{array}$ & $\begin{array}{l}0 \\
1 \\
3 \\
5\end{array}$ \\
\hline Check & $\begin{array}{ll}0 & -0 \\
0 & -.08 \\
0 & -0 \\
0 & -.01\end{array}$ & $\begin{array}{l}0 \\
1 \\
3 \\
5\end{array}$ \\
\hline
\end{tabular}


down very rapidly because of their inherent volatility. Disappearence by normal weathering processes and by dilution can also be important factors. Stears (7) found that, in Florida, temperature is one of the most important factors affecting the loss of parathion from the foliage. He was able to show that, under a fairly high temperature of approximately $78^{\circ} \mathrm{F}$. in October,

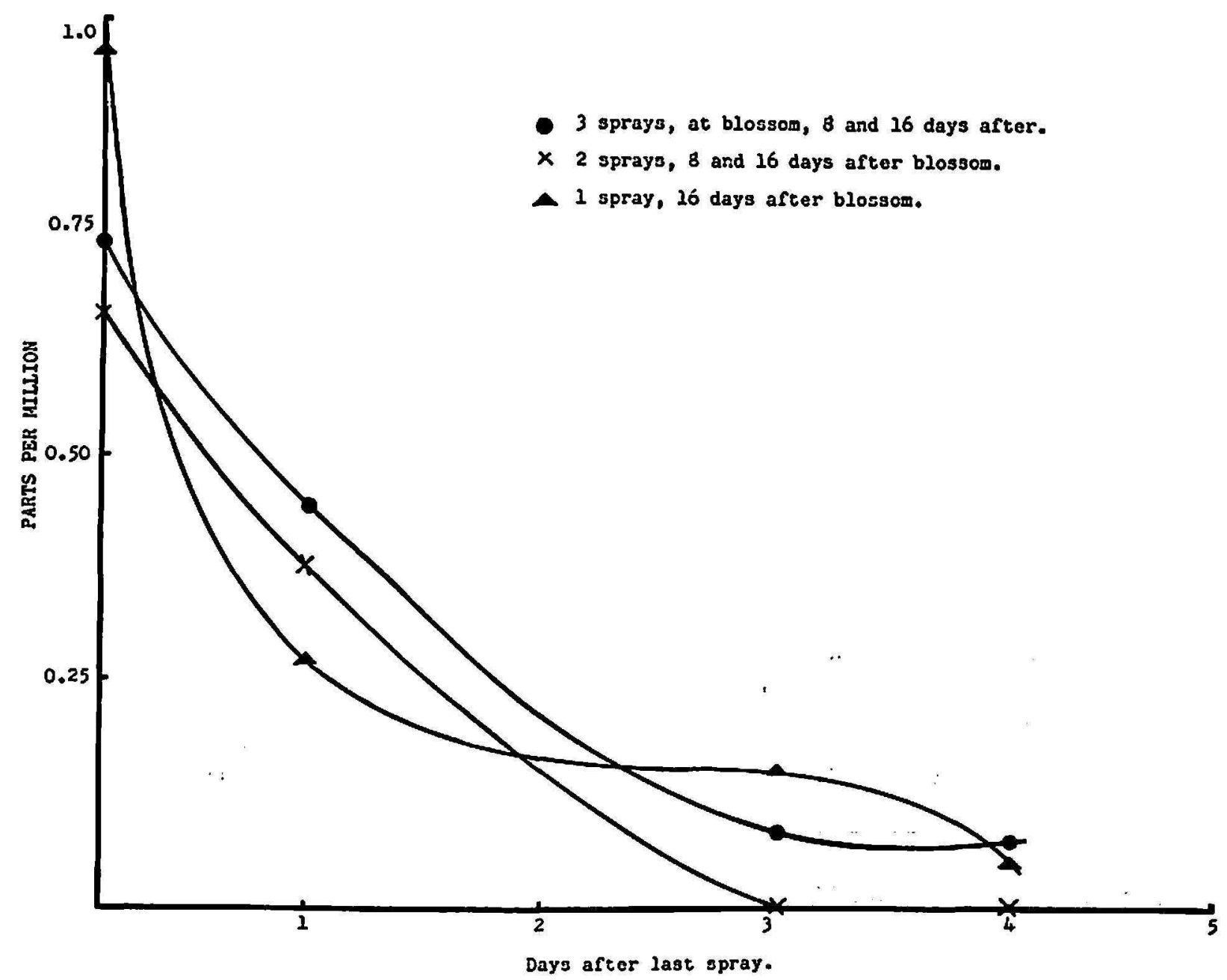

Fig. 1.-Disappearence curves for parathion residues on West Indian cherries after spray schedules indicated in experiment 1 .

90 percent loss of parathion was recorded at the end of 3 days. Under the lower temperatures of November $\left(62^{\circ} \mathrm{F}\right.$.) the same loss was recorded at the end of 4 days.

The minimum and maximum average temperatures recorded at the Isabela trials were $67^{\circ} \mathrm{F}$. and $90^{\circ} \mathrm{F}$., respectively. It seems evident that a more rapid volatilization should be expected under these conditions. Other possible contributing factors were precipitation (4.15 to 7.03 inches during the experimental periods) and the constant breeze characteristic of the area. 


\section{SUMMARY}

This paper presents the data obtained in three field experiments on parathion residues left in fresh West Indian cherries (acerolas) and their juice after spraying with parathion at different time intervals. In the first two experiments the data show that parathion residues in the fresh acerola

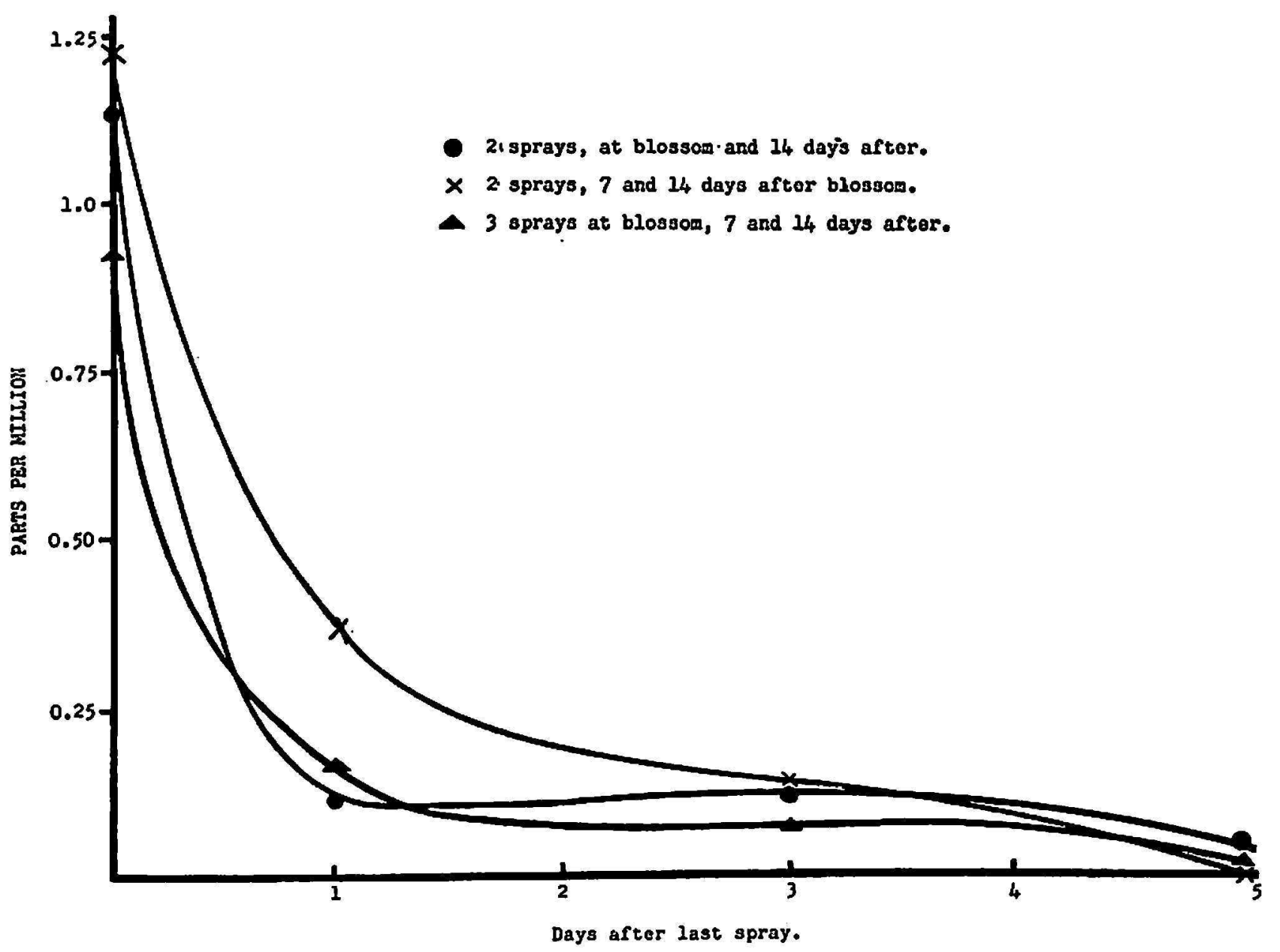

Frg. 2.-Disappearence curves for parathion residues on West Indian cherries after spray schedules indicated in experiment 2 .

were below 1 p.p.m., the first day after the last spray. Parathion residues practically disappear after the fourth day. In the third experiment, the parathion residue in the juice was well below tolerance for other fruit crops.

These results were broadly explained on the basis of the weather conditions present in Puerto Rico and the inherent volatility of parathion.

\section{RESUMEN}

En este trabajo se presentan los resultados obtenidos de tres experimentos de campo sobre residuos de Parathion en la fruta fresca y en el 
jugo de acerola, después de asperjar los árboles de acerola con este insecticida a distintos intervalos de tiempo. En los dos primeros experimentos, los residuos de Parathion estuvieron bajo 1 p.p.m. después del primer día, y desaparecieron prácticamente al cuarto día. En el tercer experimento, los residuos de Parathion del jugo de acerola estuvieron muy por debajo de la tolerancia acordada para otras frutas.

En general, los resultados se explicaron a base de las condiciones climáticas de Puerto Rico y de la volatilidad inherente del Parathion.

\section{LITERATURE CITED}

1. Unpublished data of junior author, M. E. Pérez.

2. Waites, R. E., and Van Middelem, C. H., Residue studies of toxaphene, parathion, and malathion on some Florida vegetables, J. Econ. Ent. 48 590-4, 1955.

3. Van Middelem, C. H., and Wilson, J. W., Parathion residues on celery, J. Econ. Ent. 48 88-90, 1955.

4. Roldán, J., Parathion residue studies on acerola, J. Agr. Univ. P.R. 43 147-51, 1959.

5. Garcia, M. G., Evaluation of the Averell and Norris method for the determination of Parathion in West Indian Cherry (Malpighia punicifolia, L.), J. Agr. Univ. P.R. 45 50-3, 1961.

6. Wylie, W. D., Determination of insecticide residues in soil by using Drosophilia, J. Econ. Ent. 49 638-46, 1956.

7. Stears, R. Jr., A preliminary report on parathion residues on citrus, Fla. Ent. 32 $145-9,1949$. 